\title{
Bone Marrow Ablation
}

National Cancer Institute

\section{Source}

National Cancer Institute. Bone Marrow Ablation. NCI Thesaurus. Code C15569.

The destruction of bone marrow using radiation or drugs. 